\title{
Analisisi Efisiensi Penggunaan Data Berbasis Digitalisasi Dan Keamanan Arsip pada PT Angkasa Pura II Jakarta Periode 2019 - 2020 (24 Bulan) (Studi Kasus Dimasa Pandemi Covid-19)
}

\author{
Sri Retnaning Sampurnaningsih ${ }^{1}$, Agus Suharyadi ${ }^{2}$, Nani Rusnaeni ${ }^{3}$, \\ Juni Sukasmono ${ }^{4}$, Retno Wulansari ${ }^{5}$ \\ Universitas Pamulang, Banten \\ E-mail: 1dosen01366@unpam.ac.id; 2agus.suharyadi95@gmail.com; \\ 33osen00708@unpam.ac.id; 4juni.sukasmono@eatwell.co.id; \\ 5dosen00568@unpam.ac.id
}

\begin{abstract}
ABSTRAK
Kemajuan teknologi di era 4.0 ini membuat teknologi digitalisasi berkembang semakin pesat dimana informasi dapat lebih cepat diperoleh dan hal ini tentunya berdampak pada efisiensi penggunaan data di perusahaan. Penelitian ini bertujuan untuk menganalisis efisiensi penggunaan data berbasis digitalisasi data dan keamanan arsip pada PT Angkasa Pura II, dimasa pandemik Covid-19. Metode yang digunakan dalam penelitian ini adalah asosiatif kausal dengan analisis regresi linear berganda, uji asumsi klasik dan uji hipotesis. Sampel dalam penelitian ini menggunakan data yang didigitalisasi, keamanan data dan frekuensi penggunaan data. Hasil dari penelitian ini adalah digitalisasi data (X1) menunjukkan pengaruh yang signifikan terhadap efisiensi penggunaan data $(Y)$. Keamanan arsip (X2) menunjukkan pengaruh yang signifikan terhadap efisiensi penggunaan data (Y). Selanjutnya bahwa digitalisasi data dan keamanan arsip secara simultan berpengaruh signifikan terhadap efisiensi penggunaan data. Secara statistic bahwa koefisien determinasi dengan nilai $\mathrm{R}$-square sebesar 0,489 menandakan bahwa kontribusi digitalisasi data dan keamanan arsip terhadap efisiensi penggunaan data adalah sebesar $48,9 \%$ dan sisanya sebesar $51,1 \%$ dapat dijelaskan dari variabel lain. Dapat disimpulkan bahwa dengan perkembangan teknologi digitaliasi, masyarakat dipermudah dalam pengguanan data. Perkembangan teknologi digitalisas baik secara langsung maupun tidak langung telah mempengaruhi kinerja perusahaan dimana menjadi lebih efisien dalam penggunaan datanya sehingga berdampak lebih cepat informasi yang didapat yang dapat mendukung proses pengambilan keputusan dalam suatu perusahan.
\end{abstract}

Kata kunci : Digitalisasi, Keamanan Arsip, Efisiensi Pengunaan Data

\begin{abstract}
Technological advances in the 4.0 era have made digitalization technology develop more rapidly where information can be obtained more quickly and this of course has an impact on the efficiency of data use in the company. This study aims to analyze the efficiency of data use based on data digitization and archive security at PT Angkasa Pura II, during the Covid-19 pandemic. The method used in this study is causal associative with multiple linear regression analysis, classical assumption test and hypothesis testing. The sample in this study uses digitized data, data security and frequency of data usage. The results of this study are data digitization (X1) shows a significant effect on the efficiency of data use $(Y)$. Archive security (X2) shows a significant effect on the efficiency of data use $(Y)$. Furthermore, data digitization and archive security simultaneously have a significant effect on the efficiency of data use. Statistically, the coefficient of determination with an R-square value of 0.489 indicates that the contribution of data digitization and archive security to the efficiency of data use is $48.9 \%$ and the remaining $51.1 \%$ can be explained from other variables. It can be concluded that with the development of digitalization technology, it is easier for people to use data. The development of digitalization technology, both directly and indirectly,
\end{abstract}


has affected the company's performance which is becoming more efficient in the use of its data so that it has an impact on faster information obtained that can support the decision-making process in a company.

\section{Keywords: Digitization, Archive Security, Data Use Efficiency}

\section{PENDAHULUAN}

Tata kelola naskah, yang juga dikenal sebagai sistem manajemen dokumen di suatu perusahaan, merupakan kebutuhan esensial untuk meningkatkan ketertiban administrasi dan keseragaman sistem manajemen kantor. Dengan kebutuhan akan media penyimpanan yang besar, penerbitan, pencetakan, dan otomatisasi alur kerja telah menjadi suatu keharusan bagi bisnis. Hal ini mendorong penggunaan teknologi digital yang dapat memberikan solusi yang saling terkait dengan menggabungkan beberapa media [1,].

Bukti pertanggungjawaban pekerjaan dalam setiap perusahaan maupun organisasi adalah dalam bentuk arsip yang harus selalu dijaga, dipelihara dan dilindungi. Namun, tidak semua record diperlakukan sama karena memiliki nilai penggunaan yang berbeda. Dari nilai utilitas ini, penggunaan arsip sebagai pusat memori, sumber informasi dan bantuan pengambilan keputusan untuk manajemen sangat ditentukan. Perlindungan tehadap arsip tertuang dalam "Undang-Undang Nomor 43 Tahun 2009 tentang Kearsipan. Ketentuan pelaksanaannya tertuang dalam PP RI Nomor 28 Tahun 2012 tentang Pelaksanaan Undang-Undang Nomor 43 Tahun 2009 tentang Kearsipan. Untuk pengelolaan arsip perusahaan, UU No. 8 Tahun 1997 tentang Dokumen Perusahaan".

Digitalisasi data adalah penting dalam system manajemen dokumen dimana merupakan proses pengalih media informasi analog ke media digital seperti yang telah diteliti oleh Atmoko [1] dan bahwa digitalisai merupakan upaya pelestarian arsip dan digunakan untuk mempertahankan aksesibilitas dokumen sehingga dapat memberikan askes seluas-luasnya kepada masyarakat yang membutuhkannya. Selain itu dengan adanya digitalisasi arsip dapat digunakan untuk keperluan penelitian, dokumentasi dan publikasi yang ditegaskan. Selanjutnya bahwa digitalisasi adalah proses mengubah sesuatu yang bersifat fisik dan analog menjadi sesuatu yang virtual dan digital. Hal ini sejalan dengan penelitian Sugiharto dkk. [2] yang mengatakan bahwa proses digitalisasi dari bentuk kertas membutuhkan peralatan flatbed scanner atau kamera set pada meja flatbed. Secara singkat dapat dikatakan bahwa digitalisasi adalah proses mengubah sesuatu yang bersifat fisik dan analog menjadi sesuatu yang virtual dan digital.

Dalam penelitian Sambas dan Hendri mengatakan bahwa ada dua tujuan dilakukannya alih media arsip, yaitu untuk mempercepat layanan akses (aktif dan inaktif), dan untuk pelestarian arsip (statis) [3]. Tujuan alih media arsip untuk mempercepat layanan akses arsip, dilakukan terkait tujuan pengelolaan arsip yang efektif dan efisien. Selanjutnya Sambas dan Hendri Menyusun tahapan yang dapat dilakukan dalam kegiatan penyimpanan arsip digital, khususnya yang terkait alih media arsip dari media kertas ke media elektronik (komputer) adalah sebagai berikut:

1. Menyiapkan surat/naskah dinas yang akan dialihmediakan.

2. Melakukan scanning terhadap naskah/surat.

3. Membuat folder-folder pada komputer, sebagai tempat penyimpanan surat atau naskah dinas yang telah di-scan.

4. Membuat hyperlink yaitu menghubungan antara daftar arsip dengan arsip hasil scan.

5. Membuat kelengkapan administrasi alih media.

Tujuan mem-backup arsip tidak hanya sebatas mem-backup file arsip penting yang berisi informasi, tetapi juga bagaimana kita menjaga arsip tersebut dengan baik dan benar agar tidak rusak [4]. Ada dua aspek penting dalam membuat cadangan dan memelihara catatan. Salah satunya adalah pengamanan dan pemeliharaan arsip dari 
faktor-faktor yang merusak fisik arsip. Kedua, bahwa pengamanan dan pemeliharaan bahan arsip dari lingkungan penyimpanan arsip [5,6].

Undang-undang Nomor 7 tahun 1971 menetapkan tentang ketentuan-ketentuan pokok kearsipan, pengamanan arsip dari segi fisiknya adalah pengamanan arsip dari segi kerusakan. Kerusakan arsip dapat terjadi karena faktor internal dan eksternal. Faktor internal meliputi tinta, kualitas kertas, dan bahan perekat [7]. Faktor eksternal seperti suhu, kelembaban, sinar matahari, polusi udara, jamur dan sejenisnya, dan berbagai jenis serangga perusak kertas. Keamanan Arsip adalah program untuk melindungi informasi fisik dan arsip berdasarkan klasifikasi keamanan yang telah ditentukan [8]. Klasifikasi keamanan arsip adalah pengelompokan arsip pada tingkat tertentu berdasarkan dampak jika informasi yang terkandung di dalamnya diketahui oleh orang yang tidak berwenang.

Sistem klasifikasi keamanan dan akses arsip ini ditetapkan oleh pimpinan pencipta arsip berdasarkan pedoman yang ditetapkan oleh Kepala Arsip Nasional Republik Indonesia (ANRI), keamanan arsip merupakan pengkategorian atau penggolongan arsip berdasarkan pada tingkat keseriusan dampak yang ditimbulkan terhadap kepentingan dan keamanan negara, publik serta perorangan. Sedangkan pengamanan dan upaya menyelamatkan informasi yang terkandung dalam arsip dapat dilakukan dengan mengalih-mediakan ke dalam bentuk media lain, seperti pada micro film, fich, dan ke media lain $[9,10]$.

Di masa pandemik Covid-19 dari tahun 2019 hingga saat ini berdampak pada berbagai sektor, terutama sistem kerja di semua perusahaan. Penerapan sistem work from home menggunakan konsep bekerja secara online di bawah pengawasan perusahaan. Penelitian ini mengambil kasus dimana pandemik untuk melihat perubahan sistem kerja yang dapat mempengaruhi proses digitalisasi dan penggunaan data yang telah didigitalisasi pada PT Angkasa Pura II periode 2019 - 2020 (24 bulan).

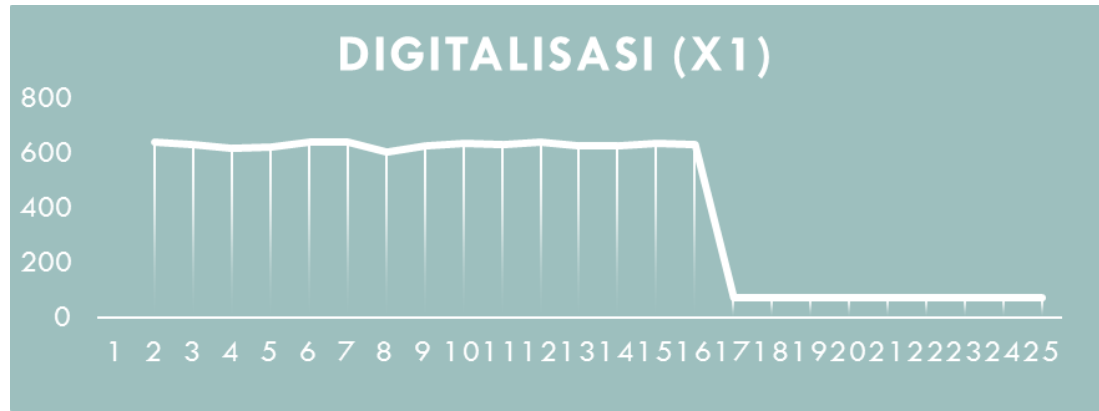

Gambar 1. Digitalisasi

Berdasarkan Gambar 1. Di atas memperlihatkan trend dari proses digitalisasi data pada Human Capital Center PT Angkasa Pura II periode 2019 - 2020 (24 bulan), dimana pada tahun 2019 proses digitalisasi data stabil, namun dampak dari pandemi Covid 19 ini terlihat pada bulan april 2020 yang menurun tajam, disebabkan karena para pegawai dibagian pengarsipan menjalankan Work Form Home (WFH), dan mempengaruhi proses digitalisasi. 


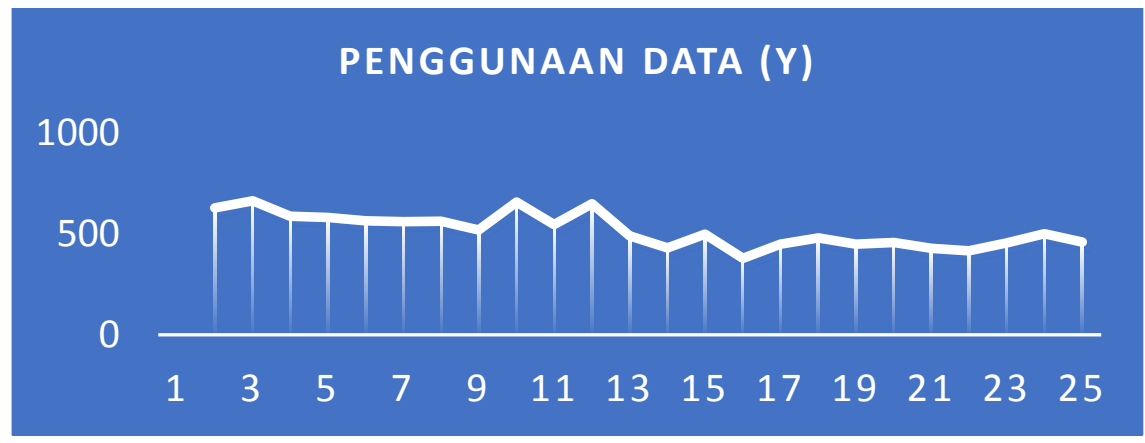

Gambar 2. Penggunaan Data

Berdasarkan Gambar 2. Di atas memperlihatkan trend dari penggunaan data, dimana terjadi penurunan pengguna data dimasa pandemi Covid-19.

\section{METODOLOGI PENELITIAN}

Jenis penelitian ini adalah asosiatif kausal, yang bertujuan untuk mengetahui hubungan antara dua variabel atau lebih. Dengan demikian diharapkan ada suatu teori yang dapat menjelaskan, meramal dan mengontrol suatu gejala maupun hipotesis. Dalam penelitian ini dikumpulkan data dan dinyatakan dalam angka-angka dengan tujuan untuk dapat mengungkap permasalahan yang diteliti. Dalam penelitian tentang pengaruh digitalisasi dan keamanan arsip terhadap efektivitas penggunaan data sebagai objek penelitian adalah PT Angkasa Pura II Jakarta.

Data yang digunakan dalam penelitian ini adalan merupakan catatan, fakta-fakta dari suatu kegiatan yang terdiri dari angka-angka yang menunjukkan suatu kondisi atau situasi dan lainya, yang diambil dari bagian administrasi yang mempunyai tugas dalam pengaturan data yang diolah dengan teknologi computer dan internet.

Dalam penelitian ini, populasi adalah seluruh data yang diambil dari PT Angkasa Pura II Jakarta yang terdiri dari 16 tipe data dan memiliki total 38.717 data. Dan sampel yang digunakan dalam penelitian ini adalah sebagian dari populasi, yaitu Data Keuangan dan kepegawaian, selama masa pandemi (2019-2020), pada Angkasa Pura II Jakarta, total 10117.

Teknik analisis data yang digunakan adalah kuantitatif deskriptif dimana data dimasa lalu dari data kepegawaian, data keuangan, data frekuensi penggunaan data dianalisis untuk dipahami hubungan antara variabelnya dan ditarik kesimpulan dari data sampel tersebut dengan pendugaan sementara (hipotesis) yaitu bahwa ada saling hubungan pengaruh diantara variable penelitian.

\section{HASIL PENELITIAN DAN PEMBAHASAN Deskripsi Data}

Berdasarkan uji asumsi klasik bahwa yaitu uji normalitas memperlihatkan grafik $\mathrm{P}$ plot dengan titik titik yang menyebar di sekitar garis diagonal dan mengikuti arah garis diagonal, yang menandakan bahwa data terdistribusi normal. Pada uji multikolinearitas yaitu ingin menguji apakah dalam model regresi ditemukan adanya korelasi antar variabel bebas (independen). Hasil memperlihatkah bahwa nilai tolerance untuk semua variabel independen adalah 0,842 $>0,10$ dan nilai variance inflation factor (VIF) sebesar $1,188<10$, sehingga dapat disimpulkan tidak terdapat multikolinearitas pada model regresi.

Selanjutnya pada Uji heteroskedastisitas dengan menggunakan grafik scatterplot terlihat bahwa Titik-titik tersebar secara acak, baik di atas maupun di bawah angka 0 pada sumbu $Y$, sehingga tidak terjadi heteroskedastisitas dari penelitian ini dan model regresi pada penelitian ini dapat digunakan. Terakhir pada Uji autokorelasi, nilai Durbin 
Watson (DW) sebesar 1,666; dan nilai DU dapat dilihat pada tabel Durbin Watson dengan sampel (n) 24 dan jumlah variabel bebas adalah 2, maka nilai $D U=1,5464$ dan $\mathrm{DI}=1,1878$. Berdasarkan uji autokorelasi Du $<$ Dw $<4$-DU, yaitu 1,5464 $<1,666<[2,4536$. Sehingga dapat disimpulkan bahwa tidak adanya autokorelasi positif atau negatif.

Terdapat Pengaruh positif Digitalisasi Data terhadap Efisiensi Penggunaan Data Pada PT Angkasa Pura II Jakarta, Saat Pandemik Covid-19 dan signifikan

Hasil penelitian ini mengindikasikan bahwa pentingnya digitalisasi data pada PT Angkasa PURA II, karena dapat meningkatkan efisiensi pengunaan data pada perusahaan tersebut. Karyawan dapat dengan cepat mengakses data walaupun kerja dari jarak jauh. Namun dengan adanya pandemic covid 19 menyebabkan karyawan bekerja di rumah yang menyebabkan proses digitalisa data terhambat karena keterbatasan fasilitas pada karyawannya.

Sistem pengelolaan dokumen dengan proses alih media atau digitalisasi data sangat esensial pada PT Angkasa PURA II dimana memberikan pelayanan data yang cepat bagi yang membutuhkan dan ini mendorong penggunaan teknologi digital pada bidang lainnya. Hasil penelitian ini didukung oleh penelitian terdahulu yaitu Yakin Bakhtiar Siregar (2019), yang mengatakan bahwa sistem manajemen data digital memudahkan pengelolaan proses administrasi dan membantu memenuhi kebutuhan masa depan, sesuai dengan "Peraturan Perundangan-undang no 8 tahun 1997, tentang dokumen perusahaan. Begitu juga penelitian dari Veraniansyah \& Sukma "yang mengatakan bahwa terhadapa pengaruh positif signifikan antara digital terhadap efisiensi waktu kerja hal ini menandakan semakin baik digitalisasi data akan mengakibatkan semakin meningkatnya efisiensi waktu kerja pada Dinas Pananaman Modal dan Pelayanan Terpadu satu pintu Denpasar" [1].

\section{Terdapat Pengaruh positif Keamanan Arsip karena terhadap Efisiensi Penggunaan Data Di PT Angkasa Pura II Jakarta, Saat Pandemik Covid-19 dan signifikan}

Hasil penelitian ini mengindikasikan bahwa pentingnya Keamanan arsip pada penyimpanan data karena keamanan data berpengaruh signifikan terhadap efisiensi penggunaan data di PT Angkasa Pura II. Keamanan arsip adalah salah satu upaya untuk memelihara arsip elektronik untuk mencegak kerusakan terhadap data elektronik agar terhindar dari virus, suhu ruangan yang perlu diatur agar terhindar dari kerusahan data digital akibat suhu ruangan yang panas dan lembab dan kemanan lainnya. Keamanan arsip elektronik memudahkan karyawan untuk menyimpan dan menggunakan data. Penelitian ini sejalan dengan penelitian Wellie yang mengatakan hal yang sama bahwa keamanan arsip elektronik memudahkan pihak yang sah untuk menyimpan dan mengambil arsip [12].

Terdapat Pengaruh Digitalisasi Data dan Keamanan Arsip secara simultan terhadap Efisiensi Penggunaan Data Di Angkasa Pura II Jakarta dan signifikan.

Hasil penelitian ini mengindikasikan bahwa pentingnya digitalisasi data dan keamanan arsip terhadap efisiensi pengunaan data PT. Angkasa Pura II (Persero), data dengan mudah dan cepat diperoleh sesuai dengan kebutuhan karyawan pada perusahaan tersebut. Hal ini membantu terlaksananya pelayanan kepada masyarakat yang membutuhkan informasi dengan cepat.

Hasil penelitian sebelumnya menyatakan bahwa digitalisasi data dan keamanan arsip berpengaruh signifikan terhadap efisiensi waktu kerja [13]. Dengan kata lain, semakin baik sistem arsip digital dan semakin baik keamanan arsip, maka akan semakin efisien jam kerja di Kantor Penanaman Modal serta Pelayanan terpadu di Denpasar. Tentu saja, ini merupakan penanganan data yang lebih efisien

Kontribusi digitalisasi data dan keamanan arsip terhadap efisiensi penggunaan data sebesar $48,9 \%$ dan sisanya sebesar $51,1 \%$ dijelaskan oleh variabel lain. Hal ini mengindikasikan bahwa peran penting dari digitalisasi data dan keamanan arsip terhadap efisiensi penggunaan data pada PT Angkasa Pura II sebesar 48.9\%. Hal 
lainnya seperti infrastruktur atau fasilitas pada perusahaan tersebut perlu diperhatikan karena keterlibatan factor lainnya dapat berperan penting pula pada efisiensi penggunaan data pada perusahaan tersebut [14].

\section{KESIMPULAN}

Berdasarkan hasil pengujian dan analisis yang dilakukan, dalam penelitian ini dapat diambil kesimpulan sebagai berikut:

1. Terdapat pengaruh positif digitalisasi data yang signifikan terhadap efisiensi penggunaan data, pada Angkasa Pura II Jakarta, disaat pandemik Covid-19. Penelitian ini menjelaskan akan pentingnya proses digitalisasi pada PT Angkasa Pura II dimana dengan digitalisasi data, data dapat diperoleh dengan mudah dan cepat sehingga membantu operasional di perusahaan tersebut. Jadi dengan adanya Digitalisasi sangat membantu penyelenggaraan proses administrasi dimana proses tersebut dapat lebih mudah, dan akan membantu memenuhi kebutuhan masa depan, hal ini sejalan dengan peraturan, "UU No 8 tahun 1997 tentang Dokumen Perusahaan dan UU No 7 tahun 1971".

2. Terdapat pengaruh positif keamanan arsip yang signifikan terhadap efisiensi penggunaan data, pada Angkasa Pura II Jakarta. Dengan terjaminnya keamanan arsip di perusahaan tersebut membuat rasa aman dan arship dapat tahan lama dalam penyimpanananya. Para karyawan ikut serta peduli dalam menjaga keamanan dokumen perusahaan. Keamanan arsip elektonik memberian kemudahan dalam penyimpanan dan pengambilan arsip oleh pihak yang berwenang.

3. Terdapat pengaruh Digitalisasi data dan keamanan arsip secara simultan yang signifikan terhadap efisiensi penggunaan data, pada Angkasa Pura II Jakarta, saat pandemik Covid-19. Dengan adanya digitalisasi dan keamanan arsip membantu kelancaran pekerjaan dari para karyawannya. Di masa pandemik ini dengan kebijakan work from home, yang menjadi kendala ada fasilitas dari setiap karyawan yang masih terbatas sehingga dimasa tersebut pelayanan penggunaan data pun ikut terganggu. Oleh karena itu, peran yang penting dari digitalisasi data dan keamanan arsip membuat perlu adanya fasilitas yang mendukung proses digitalisasi dan keamanan arsip sehingga efisiensi dalam penggunaan data terjaga dengan baik

\section{DAFTAR PUSTAKA}

[1] Atmoko, Pitoyo Widhi (2015). Digitalisasi dan Alih Media. Malang: Univerisats Bramelati.

[2] Sugiharto, Agus dan Teguh Wahyono. (2015). Manajemen Kearsipan Modern. Jogja. Gava Media

[3] Junie, D. (2017). Pengaruh Sistem Digital Dan Keamanan Arsip Terhadap Efisiensi, Waktu Kerja Pada Dinas Penanaman Modal Dan Pelayanan Terpadu Satu Pintu Kota Denpasar. Public Inspiration, Jurnal Administrasi Publik, Vol. 2 No. 2 (2017). ISSN 2581-2378. Universitas Warmadewa, Denpasar.

[4] Raharjo, M. R., Ridho, I. (2019). Sistem Informasi Digitalisasi Dokumen Berbasis Multi User Studi Kasus Ditankanhut Banjarbaru. JITEKH, Vol 7, No 1, Tahun 2019, 50-54 ISSN 2338-5677 Cetak ISSN 2549-6646 Online. Universitas Harapan Medan.

[5] Sirait, E.R.E. (2016). Implementasi Teknologi Big Data di Lembaga Pemerintahan Indonesia. Puslitbang APTIKA dan IKP, Kementerian Komunikasi dan Informatika, Jurnal Penelitian Pos dan Informatika. Vol 6 No 2 (2016) 113 - 136, e-ISSN 24769266. Jakarta. 
[6] Siregar, Y.B. (2019). Digitalisasi Arsip Untuk Efisiensi Penyimpanan Dan Aksesibilitas. Jurnal Administrasi dan Kesekretarisan Volume 4 - Nomor 1 - Maret 2019, ISSN 2598-2451. Sekolah Tinggi Ilmu Komunikasi dan Sekretari Tarakanita Jakarta.

[7] Situmorang, S., Suryadinata, A. Maulana, P. (2011). Pengamanan Arsip Elektronik Menggunakan Public Key Infrastructure. Seminar Nasional Teknologi Informasi \& Komunikasi Terapan 2011 (Semantik 2011) ISBN 979-26-0255-0. Universitas Dian Nuswantoro Semarang.

[8] Undang-Undang No 7 tahun 1971. Tentang Ketentuan-Ketentuan Pokok Kearsipan perlu disesuaikan dengan perkembangan dan kebutuhan kehidupan bermasyarakat, berbangsa, dan bernegara.

[9] Undang-Undang No 8 tahun 1997. Dokumen perusahaan.

[10] Undang-Undang Nomor 06 tahun 2005. Kepala Arsip Nasional Republik Indonesia. Tentang Pedoman Perlindungan, Pengamanan, dan Penyelamatan Arsip Vital Dokumen/Arsip Vital Negara.

[11] Veraniansyah, R.D.P. \& Sukma, E.A. (2019). Prosedur Pengelolaan Arsip Untuk Keamanan Dokumen Di Rsia Puri Bunda Malang. Jurnal Administrasi dan Bisnis Volume : 13, Nomor : 1, Juni 2019. ISSN 1978-726X. Politeknik Negeri Malang

[12] Wellie A. (2020). Peran Pelatihan Dalam Meningkatkan Kinerja Sumber Daya Manusia Di Masa Covid-19. Jurnal Pendidikan Akuntansi e-ISSN 2620-5866 (Online), Vol. 3 No. 3 Desember 2020 Halaman 186-194. Universitas Muhammadiyah Surabaya

[13] Widiatmoko A.P. (2017). Pengelolaan Arsip Di Era Digital: Mempertimbangkan Kembali Sudut Pandang Pengguna. Jurnal Diplomatika Volume 1 No. 1 September 2017 Hal 1- 11. Universitas Gajah Mada Jogyarta

[14] Zulfa, L.L, \& Mujibah, E.M., \& Rajaguguk, F. (2020). Pelatihan Penggunaan Perangkat Berbasis Internet dalam Pengumpulan Data Penelitian Masa Pandemi COVID-19. Jurnal Pengabdian Kepada Masyarakat. p-ISSN 2721-1541 | e-ISSN 2721-5113. Universitas Djuanda Ciawi. 